\title{
Sentinel lymph node detection and accuracy in vulvar cancer: Experience of a tertiary center in Turkey
}

\author{
Vulva kanserinde sentinel nod uygulamasının güvenilirliği çalışması: \\ Türkiye'de bir üçüncü basamak hastanenin deneyimi
}

\author{
Nurettin Boran ${ }^{1}$, Derya Akdağ Cınk ${ }^{1}$, Zuhal Işıkdoğan², Metin Kır³, Taner Turan¹, Gökhan Tulunayl1, Mehmet Faruk Köse ${ }^{1}$ \\ 'Department of Oncology, Etlik Zübeyde Hantm Women's Health Education and Research Hospital, Ankara, Turkey \\ ${ }^{2}$ Department of Pathology, Etlik Zübeyde Hanım Women's Health Education and Research Hospital, Ankara, Turkey \\ ${ }^{3}$ Department of Nuclear Medicine, Ankara University Faculty of Medicine, Ankara, Turkey
}

\section{Abstract}

Objective: To explore the accuracy of sentinel lymph node (SLN) dissection in predicting regional lymph node status by using either only Technetium-99m-labelled (Tc-99m) or in combination with a blue dye in patients with squamous cell cancer of vulva.

Material and Methods: Twenty-one patients who had T1 $(\leq 2 \mathrm{~cm})$ or T2 $(>2 \mathrm{~cm})$ tumors that did not encroach into the urethra, vagina or anus were included in the study. For the first twelve patients, Tc-99m was used for SLN identification, and the combined technique was used in subsequent patients. Preoperatively, Tc-99m and a blue dye was injected intradermally around the tumor. Following SLN dissection, complete inguinofemoral lymphadenectomy was performed.

Results: We could detect SLN in all 21 patients (100\%) by either Tc$99 \mathrm{~m}$ or the combined method. SLN was found to be histopathologically negative in 13 groins via Tc-99m and 10 groins via the combined method. Twenty-one of these 23 (91.3\%) groin non-SLN were also negative, but in two groins, we detected metastatic non-SLN.

Conclusion: Although SLN dissection appears promising in vulvar cancer, false negative cases are reported in the literature. Sentinel lymph node dissection without complete lymphadenectomy does not seem appropriate for routine clinical use, since it is known that groin metastasis is fatal. (J Turkish-German Gynecol Assoc 2013; 14: 146-52) Key words: Sentinel node, lymph node, vulvar cancer

Received: 30 May, 2013

Accepted: 18 July, 2013
Özet

Amaç: Vulva kanserli hastalarda teknesyum-99m (Tc-99m) veya mavi boya (blue dye) kullanılarak yapılan sentinel lenf nodu (SLN) diseksiyonlarının hastaların lenf nodu tutulumların göstermedeki başarısını belirlemek.

Gereç ve Yöntemler: Üretra, vajina ya da anüste tutulumu olmayan T1 $(\leq 2 \mathrm{~cm})$ ya da T2 $(>2 \mathrm{~cm})$ tümörü olan 21 vulva kanserli hasta çaış̧maya dahil edildi. Çalışmanın ilk 12 hastasında SLN'nu tespit etmek için Tc-99m kullanırken diğer hastalarda kombine teknik (Tc-99m ve blue dye) kullanıldı. Operasyon öncesinde tümör çevresine intradermal olarak Tc-99m ve blue dye enjekte edildi. SLN diseksiyonunu takiben biri hariç tüm hastalarda tamamlayıcı inguinofemoral lenfadenektomi yapildl.

Bulgular: Çalışmaya katılan 21 hastanın tümünde bilateral SLN diseksiyonu (toplam 42) yapılırken 39 tanede tamamlayıcı inguinofemoral lenfadenektomi yapıldı. Hastaların tümünde Tc-99m veya kombine metot kulllanılarak SLN tespit edildi. Tc-99m kullanılan hastaların 13 inguinal bölgesinde (groin) ve kombine metot kullanılan hastaların 10 inguinal bölgesinde SLN'u histopatolojik olarak negatif bulundu. Bu 23 inguinal bölgenin 21'inde (91.3\%) SLN olmayan lenf nodları da negatifti ancak 2 inguinal bölgede SLN olmayan lenf nodlarında metastaz tespit edildi.

Sonuç: Vulva kanserinde SLN diseksiyonlan ümit verici olsa da, literatürde yanlış negatif vakalar rapor edilmiştir. İnguinal bölge metastazları vulva kanserli hastalarda ölümcül olduğundan, tamamlayıcı inguinofemoral lenfadenektomi olmadan yapılan sentinel lenf nodu diseksiyonlarının rutin kullanım için uygunluğu tartışmalıdır.

(J Turkish-German Gynecol Assoc 2013; 14: 146-52)

Anahtar kelimeler: Sentinel nod, lenf nodu, vulva kanseri

Geliş Tarihi: 30 Mayıs 2013

Kabul Tarihi: 18 Temmuz 2013

\section{Introduction}

Vulvar squamous cell cancer is a disease of postmenopausal women, with a median age at diagnosis of about 65 years. It accounts for about $4 \%$ of genital tract cancers. The increase in incidence of vulvar intraepithelial neoplasia and life span has brought vulvar cancer into a place of more importance among genital tract cancers (1). Lymphatic spread to the inguinal and femoral lymph nodes is the major pathway of invasion in early stage vulvar cancer. The status of the regional lymph nodes is clearly the most important prognostic factor in vulvar cancer. Predictive factors of nodal involve- 
ment are the depth of infiltration, the size and the location of the tumor (2). Currently, surgery is the cornerstone of treatment in early stage vulvar cancer. Historically, all patients with vulvar cancer have been treated with radical vulvectomy and en bloc inguinofemoral lymph node dissection (LND) with a single incision. Following this aggressive surgery, morbidities have been significant with wound breakdown, chronic lymph edema in lower extremities and sexual dysfunction (3). In the past 20 years, treatment has become less invasive by performing excision of the tumor and uni- or bilateral inguinofemoral LND according to the laterality of the tumor through separate incisions. Despite these more conservative surgeries, significant morbidity has persisted. Although wound complications are generally short-lived, lymphedema is a chronic problem which requires long-term management (4). Recently, sentinel lymph node (SLN) biopsy has been introduced as an alternative in order to adequately assess for regional lymph node metastasis and to avoid the morbidity of complete inguinofemoral lymphadenectomy.

Recent data in the literature demonstrate that the SLN biopsy technique has become an integral treatment in the management of patients with early stages of breast cancer and melanoma $(5,6)$. Since the tumor is suitable for injection with a vital blue dye and/or technetium 99m and the lymphatic flow pathway is predictable, vulvar cancer is also a good target for SLN biopsy (4). Since 1994, a great number of clinical trials have been published on SLN detection and accuracy in vulvar cancer (7-17). In these clinical trials, the accuracy of SLN biopsy using a radiocolloid alone or in combination with a blue dye was demonstrated with a high negative predictive value (95\%), but false positive cases were also reported.

We performed a prospective trial to evaluate the diagnostic accuracy of performing SLN biopsy with consecutive complete inguinofemoral lymphadenectomy in predicting the status of the inguinal lymph nodes in patients with early stage vulvar cancer. The aim of the study was to examine the sensitivity of the SLN technique using either preoperative lymphoscintigraphy with a radiocolloid (technetium-99m) alone or as combination of the radiocolloid and a blue dye.

\section{Materials and Methods}

Patients with primary squamous cell cancer of the vulva were referred to our hospital as a tertiary center for further treatment between April 2000 and October 2005. Patients with T1 $(\leq 2 \mathrm{~cm})$ or $\mathrm{T} 2(>2 \mathrm{~cm})$ tumors that did not encroach in the urethra, vagina or anus were eligible for the study. All patients had histologically confirmed diagnosis of invasive squamous vulvar cancer with invasion greater than $1 \mathrm{~mm}$ in depth and were candidates for inguinal lymph node dissection. Patients with clinically palpable groin lymph nodes were excluded from the study. Patients with a prior vulvar surgery that could disrupt lymphatic drainage were also excluded from the study. None of the patients had undergone excisional biopsy for the primary lesion prior to enrollment in the study. Approval for the study was given by the medical ethics committee of the hospital. After informed consent, we prospectively studied 21 women with operable vulvar cancer. The first 12 cases underwent SLN identification with a gamma probe using a Tc-99mlabelled nanocolloid, and in the subsequent nine patients, the combined technique (Tc-99m and a blue dye) was used.

In the first 12 patients, approximately one hour before the operation, $0.4-0.6 \mathrm{~mL}$ of $\mathrm{Tc}-99 \mathrm{~m}$ microcolloidal sulfur (Lymphoscint ${ }^{\circledR}$, Nycomed-Amersham-Sorin, Germany) was injected circumferentially around the tumor via the intradermal route in each quadrant of the tumor. Sentinel lymph nodes were identified using a handheld gamma probe which identifies SLN based on high counts, usually at least 10x the basal count (Europrobe 2000, Eurorad, France); SLN were removed separately. The count rate in vivo and in vitro was examined. After removal of the first SLN, the groin was re-examined for radioactivity, and dissection continued in search of additional SLN and make sure that all SLN were identified and removed. In the subsequent nine patients, following the procedure described above, $2.0 \mathrm{~mL}$ of patent blue $\mathrm{V}$ dye $(2.5 \%$ in aqueous solution containing $0.6 \%$ sodium chloride and $0.05 \%$ disodium hydrogen phosphate; France) was injected around the tumor in a manner and location similar to the Tc-99m sulfur colloid injection. Compression and massage were applied gently in order to allow the dye to travel through the lymphatics. Fifteen minutes after dye injection, a longitudinal bilateral inguinal incision was carefully made to the point which showed the maximum color change. The bluish afferent lymphatic channel was seen and followed up to the blue sentinel lymph node (SLN). This node was then excised and counts in the node and background counts in the operative field were then checked and compared. If no blue nodes were seen, SLN were detected only by radioactivity. Afterwards, uni/bilateral inguinofemoral lymphadenectomy with local radical excision of the tumor or radical vulvectomy were performed via separate incisions. The primary tumor was excised with a free margin of at least 1-2 cm of normal skin. The removed SLN and the lymphadenectomy specimens were sent for histopathological examination separately.

For routine histopathological examination, all the lymph nodes were bisected parallel to the long axis and totally submitted for histopathological evaluation in two or more blocks. Each block was stained with hematoxylin and eosin. The two patients (number 3 and 9) who had negative SLN and positive non-SLN underwent further histopathological examination. Sentinel lymph nodes of these two patients were serially sectioned and stained with hematoxylin and eosin. The SPSS for Windows version 15.0 software (SPSS Inc., Chicago, IL, USA) was used to perform the statistical analyses of the study.

\section{Results}

\section{Patient characteristics}

From May 2000 through October 2005, 21 patients with squamous cell cancer of the vulva underwent inguinal SLN dissection and inguinofemoral LND according to the planned procedure. The mean age of the patients was $62.2 \pm 11.1$ years 
(range 45-87 years). The mean tumor size was $24.5 \mathrm{~mm}$ (range $8-40 \mathrm{~mm}$ ). Of all 21 patients, 10 had tumors greater than 20 $\mathrm{mm}$ in diameter and the other 11 patients had tumors less than or equal to $20 \mathrm{~mm}$ in diameter. The histologic type was squamous cell cancer in all patients. Tumors were located at the midline in ten patients, on the left side in five patients and on the right side in six patients.

Complete inguinofemoral LND was performed in 39 groins in this study. Out of 21 patients, 19 patients had bilateral complete inguinofemoral LND and sentinel lymph node (SLN) dissection together, while one patient (number 10) had SLN dissection with ipsilateral inguinofemoral LND and one had only SLN dissection without complete lymphadenectomy. The latter was the oldest case (87 years) in our study; she was not submitted to general anesthesia for the operation because she had a history of severe heart failure. Therefore, local excision of the tumor from the right labia majora and bilateral SLN dissection were performed under local anesthesia. All of the patients had bilateral SLN dissections. No adverse effect or allergy to the dye was observed in the study.

Sensitivity of the radioisotope and blue dye for SLN detection For the first 12 patients (patients \#1-12), a Tc-99m-labelled nanocolloid was used for SLN identification, and the blue dye was added to the procedure in the subsequent nine patients (patients \#13-21). The utilization of only the gamma probe (Tc-99m) allowed for the detection of a SLN in all of the first 12 patients (100\%). Out of 24 groin SLN dissections performed in this first group of patients, SLN were found to have tumors in seven groins, SLN were not detected in four groins and SLN were found to be tumor-free in 13 groins. Out of these 13 groins with tumor-free SLN, two groins (patients \#3 and 9) were found to have a skip metastasis in non-SLN. The false negative rate for SLNs using Tc-99m was calculated as 2/13 (15.4\%) per groin in this study. The tumor and SLN characteristics of the patients in the first group (Tc-99m) are summarized in Table 1.
With the use of the blue dye and radioisotope together, SLN were detected in all of the subsequent nine patients (100\%). Out of 18 groin SLN dissections performed in the combined method group, SLN were found to have tumors in two groins, SLN were not detected in six groins and SLN were found to be histolologically tumor-free in 10 groins. In total, 16 groins $(10+6)$ with tumor-free and absent SLN were also found to be free of tumor metastases in the other non-SLN. Therefore no skip metastases to non-SLN were found via the combined method (Tc-99m and a blue dye) by patient and by groin. The tumor and SLN characteristics of the patients in the second group (Tc-99m plus a blue dye) are summarized in Table 2.

\section{SLN characteristics}

At least one SLN was detected in all 21 (100\%) patients. Sentinel node dissection of 39 groins produced a total of 39 SLN; one SLN was identified in 26 groins, two SLN in three groins, three SLN in one groin, and four SLN in one groin. SLN could not be identified in 10 groins (four groins in the Tc-99m group and six groin in the combined method group), but the non-SLN of these groins were also free of metastases. The SLN were found to be histopathologically negative in 23 groins (13 in the Tc-99m group and 10 in the combined method group). Of all these 23 groins with tumor-free SLN, 21 groins had nonSLN which were also negative, but in two groins (patients \#3 and 9), metastatic non-SLN were also detected. The SLN of these patients (patients \#3 and 9) were subjected to further histopathological examination with serial sectioning and were again found to be free of metastases. SLN were not identified in 10 groins (four in the Tc-99m group and six in the combined method group). Of all these 10 groins with absent SLN, nonSLN were also found to be histopathologically tumor-free. SLN were found to have tumor metastases in nine groins (seven in the Tc-99m group and two in the combined method group). Of all these nine groins with tumor-positive SLN, only five groins had metastatic SLN with histologically tumor-free non-SLN and four groins had metastases in both SLN and non-SLN.

Table 1. Summary of tumor and sentinel node characteristics undergoing SLN dissection via a combined method (technetium and blue dye)

\begin{tabular}{|c|c|c|c|c|c|c|c|}
\hline Case no & Age & Tm size & Tm location & $\begin{array}{c}\text { SLN status } \\
\text { Right }\end{array}$ & $\begin{array}{c}\text { SLN status } \\
\text { Left }\end{array}$ & $\begin{array}{c}\text { Positive Nodes } \\
\text { Right }\end{array}$ & $\begin{array}{c}\text { Positive Nodes } \\
\text { Left }\end{array}$ \\
\hline 13 & 58 & $2 \mathrm{~cm}$ & Midline & Not identified & Neg & None & None \\
\hline 14 & 72 & $1.5 \mathrm{~cm}$ & Left side & Not identified & Neg & None & None \\
\hline 15 & 65 & $3 \mathrm{~cm}$ & Midline & Neg & Neg & None & None \\
\hline 16 & 48 & $3 \mathrm{~cm}$ & Midline & Pos & Pos & SN & $\mathrm{SN}$ \\
\hline 17 & 47 & $2 \mathrm{~cm}$ & Left side & Not identified & $\mathrm{Neg}$ & None & None \\
\hline 19 & 72 & $1 \mathrm{~cm}$ & Right side & Neg & Not identified & None & None \\
\hline 20 & 52 & $1.5 \mathrm{~cm}$ & Right side & $\mathrm{Neg}$ & Neg & None & None \\
\hline 21 & 72 & $3 \mathrm{~cm}$ & Right side & Neg & Not identified & None & None \\
\hline
\end{tabular}

SLN: Sentinel lymph node; Pos: Positive; Neg: Negative 
Table 2. Summary of tumor and sentinel node characteristics undergoing SLN dissection via technetium-99m

\begin{tabular}{|c|c|c|c|c|c|c|c|}
\hline Case no & Age & Tm size & Tm location & $\begin{array}{l}\text { SLN status } \\
\text { Right }\end{array}$ & $\begin{array}{c}\text { SN status } \\
\text { Left }\end{array}$ & $\begin{array}{c}\text { Positive Nodes } \\
\text { Right }\end{array}$ & $\begin{array}{c}\text { Positive Nodes } \\
\text { Left }\end{array}$ \\
\hline 1 & 45 & $1.5 \mathrm{~cm}$ & Midline & Not identified & $\mathrm{Neg}$ & None & None \\
\hline 2 & 49 & $0.8 \mathrm{~cm}$ & Right side & Neg & Not identified & None & None \\
\hline 3 & 65 & $4 \mathrm{~cm}$ & Midline & Neg & Neg & None & Non-SN \\
\hline 4 & 87 & $4 \mathrm{~cm}$ & Right side & Neg & Neg & None & None \\
\hline 5 & 60 & $3 \mathrm{~cm}$ & Midline & Neg & Neg & None & None \\
\hline 6 & 49 & $3 \mathrm{~cm}$ & Right side & Pos & Pos & SN-NonSN & SN-NonSN \\
\hline 7 & 69 & $4 \mathrm{~cm}$ & Midline & Pos & Pos & $\mathrm{SN}$ & SN-NonSN \\
\hline 8 & 65 & $1.5 \mathrm{~cm}$ & Left side & Not identified & Neg & None & None \\
\hline 9 & 65 & $2 \mathrm{~cm}$ & Midline & Pos & $\mathrm{Neg}$ & SN-NonSN & NonSN \\
\hline 10 & 75 & $3.5 \mathrm{~cm}$ & Midline & Not identified & Pos & None & $\mathrm{SN}$ \\
\hline 11 & 58 & $4 \mathrm{~cm}$ & Left side & Neg & Pos & None & SN-NonSN \\
\hline 12 & 69 & $1.7 \mathrm{~cm}$ & Left side & Neg & Neg & None & None \\
\hline
\end{tabular}

Inguinofemoral lymphadenectomy and non-SLN characteristics In total, 39 groin dissections (completion inguinofemoral lymphadenectomy) were performed and the average number of total lymph nodes sampled were 8,4 nodes per groin. Among the 39 groins dissected, 11 groins were found to have tumor metastases. Of 11 groins, nine groins had tumor positive SLN whereas the other two groins (patients \#3 and 9) had false negative SLN with metastatic non-SLN. Of these 11 groins, four contained metastasis to the SLN with negative non-SLN and seven had metastatic SLN and non-SLN together. If we look on the basis of patients, out of the 21 patients who participated in the study, six patients in the Tc-99m and one patient in the combined method group were found to have tumor metastases in the groin. Out of the six patients in the Tc-99m group, five patients had at least one histopathologically positive SLN detected and complete bilateral lymphadenectomy was performed in this group of patients. On the other hand, one patient (patient \#3) had tumor-free SLN on both the right and left side but tumor positive non-SLN were found in the left groin after complete lymphadenectomy was done. If we had performed only SLN dissection without complete inguinofemoral LND in this case, she would have had inadequate surgical treatment and probably reduced diseasefree survival. The average sizes of the tumors in the patients with groin metastases and the size of the tumor in the patient with a false negative SLN (patient \#3) were $2 \mathrm{~cm}$ and $4 \mathrm{~cm}$, respectively.

Tumor location and SLN characteristics

Out of 10 cases who had tumors at the midline (clitoris fourchette and perineum), only six (60\%) were found to have bilateral sentinel nodes. Among the subsequent 11 cases who had tumors located laterally more than $2 \mathrm{~cm}$ from the midline, six had ipsilateral sentinel lymph nodes.

\section{Discussion}

According to our literature search, this is the first prospective clinical trial investigating the feasibility and accuracy of SLN dissection in the surgical management of early stage vulvar cancer in Turkey. For the first 12 patients, a radiocolloid was used for SLN dissection and a combined method (radiocolloid and a blue dye) was used in the subsequent nine patients. We successfully detected at least one SLN in each of all 21 patients with vulvar cancer.

Levenback et al. (13) first reported the use of a blue dye for SLN detection in seven of 12 (58\%) groin dissections in 1994. They reported SLN identification in 57 out of 76 (75\%) cases in a later article (14). Other studies in which Tc-99m was used for SLN dissection have demonstrated that SLN can be detected easily in the majority of patients. In the studies by Merisio et al. (17) and Moore et al. (16), sentinel nodes were detected with the use of Tc-99m in $100 \%$ of cases. Many other investigators have used the combined technique (Tc-99m and a blue dye) in order to identify sentinel nodes more accurately. De Hullu et al. (18) and Martinez-Palones et al. (10) reported a $100 \%$ sentinel lymph node detection rate with the use of the combined technique. Recently, the results of a GOG protocol investigating whether SLN dissection could replace complete inguinofemoral lymphadenectomy were published, and the SLN detection rate was reported to be $92.5 \%$ in 452 patients with squamous cell vulvar cancer (4). Hassanzade et al. (19) analyzed forty-nine studies in the literature in a systematic review; the SLN detection rate per patient and per groin were found to be $94.4 \%$ and $84.6 \%$, respectively in this meta-analysis. Since radiocolloid use is associated with a better detection rate compared to the blue dye alone, blue dye might be used if only radiocolloid fails to detect the sentinel node. Recently, fluorescent dyes and near infrared (NIR) optical imaging have been introduced for SLN identification. However due to the 
limited penetration of NIR fluorescence, radiocolloids are still essential for the detection of SLN, especially more deeply located ones (20).

Inguinal lymph node status is the most important prognostic factor in patients with early-stage vulvar cancer. Since local inguinal lymph node metastasis is fatal, the determination of lymph node status is very important (21). In a meta-analysis of studies investigating methods of detecting lymph node metastases in vulvar cancer, SLN dissection was found to be the most accurate way of diagnosing lymph node status (sensitivity of 97\%). Other alternative approaches to detect lymph nodes, like groin ultrasound with or without fine needle aspiration, computerized tomography, magnetic resonance imaging and positron emission tomography had sensitivities ranging from $45 \%$ to $86 \%$ (22).

SLN dissection was introduced in order to adequately predict the status of other non-sentinel lymph nodes and to decrease the complications of aggressive surgery. Negative SLN should indicate the absence of tumor metastases in other non-sentinel lymph nodes, but in our study, two patients with negative SLN were found to have non-sentinel lymph node metastases. Although we are sure that the SLN were histologically tumorfree (ultrastaging and immunohistochemical examination were also negative for the presence of tumors in these lymph nodes), we detected skip metastases to non-sentinel lymph nodes. Enhanced histopathological analysis with serial sectioning and immunohistochemistry have been found to be highly accurate for detecting even subclinical micrometastases in the lymphatics (8). While some authors would rather use serial sectioning and immunostaining (i.e., ultrastaging) of SLN to search for micrometastases, the optimal method (hematoxylin and eosin satin versus ultrastaging) remains uncertain $(23,24)$. At present, no reliable non-invasive method is available to discriminate between patients with and without inguinofemoral lymph node metastases; therefore, in our study, routine inguinofemoral lymphadenectomy was performed in all of our patients.

Out of 23 groins with negative SLN using either only Tc-99m or the combined method, two groins were found to have skip metastases in non-SLN. The false negative rate for SLN for per groin was $2 / 23$ or $8.6 \%$. Out of 21 patients, two patients had false negative SLN in our study; although the SLN were negative in the groin, there were metastatic nonSLN. Approximately $10 \%$ (2/21 or $9.5 \%$ ) of the patients in our study had skip metastases to other regional lymph nodes. One case out of 10 is an important ratio and it is difficult to ignore because lymph node metastasis is fatal in vulvar cancer.

With the use of radiocolloid only, Merisio et al. (17) reported a case of a falsely negative lymph node in vulvar cancer. This patient was a 70-year-old obese woman with a tumor exceeding $4 \mathrm{~cm}$ in diameter. It was said that injection of higher quantities of the radiocolloid might be needed for larger tumors. Martinez-Palones et al. (10) also reported a case with a false negative sentinel node. Terada et al. (8) reported a case of a groin recurrence less than two years after apparently negative sentinel node biopsy. This node was pathologically a false negative; pathologic analysis with step sectioning and immunohistochemistry revealed micrometastases in the sentinel node. Fons et al. (25) also reported a case with detection failure in the sentinel node with a combined method; the sentinel node was detected only in one groin and exploration of the other groin showed a large $2 \mathrm{~cm}$ lymph node totally replaced with tumor tissue. Neither the radioactive material nor the blue dye could stain it. In order to minimize the risk of failure in the sentinel node procedure, preoperative selection of patients with magnetic resonance imaging was recommended in this study. Radziszewski et al. (26) reported the rate of false negative sentinel lymph nodes as $17 \%(8 / 46)$, which is inconsistent with the literature. Inadequate surgeon experience with vulvar cancer surgery was said to be the main predisposing factor for the high rate of false negative SLN. In the former study, although surgeons had at least 15 years of experience, the SLN dissection technique had only been performed a few times by each of them. There is a learning curve in performing the SLN detection technique, and de Hullu et al. (18) defined the first 10 patients as the learning phase for the SLN procedure. Early cases within the series can also lead to false negative SLN results; in our study, the two patients with false negative SLN were operated on in 2001 and 2002, respectively, and can be accepted as early cases. The SLN detection rate is also related to the size of the vulvar tumor. Patients with a tumor size exceeding $4 \mathrm{~cm}$ have not been accepted as candidates for the SLN dissection technique since the results of the GROINSS-IV study were published in 2010. The sensitivity of SLN dissection in $<4 \mathrm{~cm}$ vulvar cancer tumors was $7 \%$ higher than $>4 \mathrm{~cm}$ tumors in a meta-analysis $(93 \%$ and $86 \%$, respectively). Oonk et al. (27) also reported that when the size of a sentinel node metastasis increases, the risk of non-sentinel lymph node metastasis also increases; no cutoff value for size could be determined in order to make us sure of the absence of non-sentinel lymph node metastasis. In our study, the patients with false negative SLN had tumors $2 \mathrm{~cm}$ and $4 \mathrm{~cm}$ in size, which could also be a contributing factor to detection failure.

The literature also warns us about midline tumors of the vulva, since unilateral SLN detection can cause false negative findings on the contralateral side. The best approach should be inguinal lymphadenectomy on the detection failure groin. In our study, both of the patients with false negative sentinel nodes had midline tumors. There may be technical problems during injection of the radioisotope or blue dye, and this may result in false negative sentinel nodes. Another reason for failure may be speculated that lymph nodes fully replaced with tumor tissue can lead to the stasis of lymphatic flow, such that the real SLN is by-passed and another lymph node is assumed to be the sentinel node.

Recent data on the SLN dissection technique are impressive and suggest that this is a reliable method for the detection of SLN in vulvar malignancy $(18,28)$. In a multicenter trial, patients with negative SLN were reported to have low groin recurrence and survival. Van der Zee et al. (29) noted that SLN biopsy should be done by a quality controlled multidisciplinary team. 
We could successfully detect SLN in all patients using Tc-99m or a blue dye, but histologically tumor-free SLN do not guarantee that the remaining lymph nodes are also tumor-free. Since false negative cases have been reported both in our trial and in other studies in the literature, the SLN dissection procedure without complete inguinofemoral lymphadenectomy is not appropriate for routine clinic use in our country. Because patients with vulvar cancer generally relapse locally and groin recurrence is almost always fatal, further validation trials are necessary in order to assess the safety and accuracy of the SLN technique, especially in centers with a small number of patients with vulvar cancer.

\section{Ethics Committee Approval: N/A}

Informed Consent: Written informed concent was obtained from patients who participted in this study.

Peer-review: Externally peer-reviewed.

Author contributions: Concept - N.B., M.F.K.; Design - D.A.C.; Supervision - T.T., G.T.; Resource - Z.I., M.K.; Materials - Z.I., M.K.; Data Collection\&/or Processing - Z.I., M.K.; Analysis\&/or Interpretation - D.A.C., T.T., N.B.; Literature Search - T.T., G.T.; Writing - D.A.C.; Critical Reviews - M.F.K.

Conflict of Interest: No conflict of interest was declared by the authors.

Financial Disclosure: No financial disclosure was detected by the authors.

\section{References}

1. Makar APH, Scheistroen M, Van Den Weyngaert, Trope CG. Surgical management of stage I and II vulvar cancer: The role of the sentinel node biopsy. Review of the literature. Int $\mathrm{J}$ Gynecol Cancer 2001; 11: 255-62. [CrossRef]

2. Binder SW, Huang I, Fu YS, Hacker NF, Berek JS. Risk factors for the development of lymph node metastasis in vulvar squamous cell carcinoma. Gynecol Oncol 1990; 37: 9-16. [CrossRef]

3. Podratz KC, Symmonds RE, Taylor WF, Williams TJ. Carcinoma of the vulva: analysis of treatment and survival. Obstet Gynecol 1983; 61: 63-74.

4. Levenback CF, Ali S, Coleman RL, Gold MA, Fowler JM, Judson PL, et al. Lymphatic mapping and sentinel lymph node biopsy in women with squamous cell carcinoma of the vulva: a gynecologic oncology group study. J Clin Oncol 2012; 30: 3786-91. [CrossRef]

5. Morton DL, Wen DR, Wong JH, Economou JS, Cagle LA, Storm FK, et al. Technical details of intraoperative lymphatic mapping for early stage melanoma. Arch Surg 1992; 127: 392-9. [CrossRef]

6. Hansen NM, Grube BJ, Giuliano AE. The time has come to change the algorithm for the surgical management of early breast cancer. Arch Surg 2002; 137: 1131-5. [CrossRef]

7. Hakim AA, Terada KY. Sentinel node dissection in vulvar cancer. Curr Treat Options Oncol 2006; 7: 85-91. [CrossRef]

8. Terada KY, Shimizu DM, Wong JH. Sentinel node dissection and ultrastaging in squamous cell cancer of the vulva. Gynecol Oncol 2000; 76: 40-4. [CrossRef]

9. Vidal-Sicart S, Puig-Tintore LM, Lejarcequi JA, Paredes P, Ortega ML, Munoz A, et al. Validation and application of the sentinel lymph node concept in malignant vulvar tumors. Eur J Nucl Med Mol Imaging 2007; 34: 384-91. [CrossRef]

10. Martínez-Palones JM, Pérez-Benavente MA, Gil-Moreno A, DíazFeijoo B, Roca I, García-Jiménez A, et al. Comparison of recurrence after vulvectomy and lymphadenectomy with and without sentinel node biopsy in early stage vulvar cancer. Gynecol Oncol 2006; 103: 865-70. [CrossRef]

11. de Hullu JA, van der Avoort IA, Oonk MH, van der Zee AG. Management of vulvar cancers. Eur J Surg Oncol 2006; 32: 825-31. [CrossRef]

12. De Cicco C, Sideri M, Bartolomei M, Grana C, Cremonesi M, Fiorenza M, et al. Sentinel node biopsy in early vulvar cancer. $\mathrm{Br}$ J Cancer 2000; 82: 295-9. [CrossRef]

13. Levenback C, Burke TW, Gershenson DM, Morris M, Malpica A, Ross MI. Intraoperative lymphatic mapping for vulvar cancer. Obstet Gynecol 1994; 84: 163-7.

14. Levenback C, Coleman RL, Burke TW, Bodurka-Bevers D, Wolf $\mathrm{JK}$, Gershenson DM. Intraoperative lymphatic mapping and sentinel node identification with blue dye in patients with vulvar cancer. Gynecol Oncol 2001; 83: 276-81. [CrossRef]

15. Ansink AC, Sie-Go DM, van der Velden J, Sijmons EA, de Barros LA, Monaghan JM, et al. Identification of sentinel lymph nodes in vulvar carcinoma patients with aid of a patent blue $\mathrm{V}$ injection: a multicenter study. Cancer 1999; 86: 652-6. [CrossRef]

16. Moore RG, DePasquela SE, Steinhoff MM, Gajewski W, Steller M, Noto R, et al. Sentinel node identication and the ability to detect metastatic tumor to inguinal lymph nodes in squamous cell cancer of the vulva. Gynecol Oncology 2003; 89: 475-9. [CrossRef]

17. Merisio C, Berretta R, Gualdi M, Pultrone DC, Anfuso S, Agnese $\mathrm{G}$, et al. Radioguided sentinel lymph node detection in vulvar cancer. Int J Gynecol Cancer 2005; 15: 493-7. [CrossRef]

18. de Hullu JA, Hollema H, Piers DA, Verheijen RH, van Diest PJ, Mourits MJ, et al. Sentinel lymph node procedure is highly accurate in squamous cell carcinoma of the vulva. J Clin Oncol 2000; 18: $2811-6$.

19. Hassanzade M, Attaran M, Treglia G, Yousefi Z, Sadeghi R. Lymphatic mapping and sentinel node biopsy in squamous cell carcinoma of the vulva: Systematic review and meta-analysis of the literature. Gynecol Oncol 2013; 130: 237-45. [CrossRef]

20. Schaafsma BE, Verbeek FP, Peters AA, van der Vorst JR, de Kroon $\mathrm{CD}$, van Poelgeest MI, et al. Near-infrared fluorescence sentinel lymph node biopsy in vulvar cancer: a randomised comparison of lymphatic tracers. BJOG 2013; 120: 758-64. [CrossRef]

21. Klar M, Bossart M, Stickeler E, Brink I, Orlowska-Volk M, Denschlag D. Sentinel lymph node detection in patients with vulvar carcinoma; Feasibility of intra-operative mapping with technetium99m-labeled nanocolloid. Eur J Surg Oncol 2011; 37: 818-23. [CrossRef]

22. Selman TJ, Luesley DM, Acheson N, Khan KS, Mann CH. A systematic review of the accuracy of diagnostic tests for inguinal lymph node status in vulvar cancer. Gynecol Oncol 2005; 99: 206-14. [CrossRef]

23. Moore RG, Granai CO, Gajewski W, Gordinier M, Steinhoff MM. Pathologic evaluation of inguinal sentinel lymph nodes in vulvar cancer patients: a comparison of immunohistochemical staining versus ultrastaging with hematoxylin and eosin staining. Gynecol Oncol 2003; 91: 378-82. [CrossRef]

24. Knopp S, Holm R, Tropé C, Nesland JM. Occult lymph node metastases in early stage vulvar carcinoma patients. Gynecol Oncol 2005; 99: 383-7. [CrossRef] 
25. Fons G, Rahe ter B, Sloof G, de Hullu J, van der Velden J. Failure in the detection of the sentinel lymph node with a combined technique of radioactive tracer and blue dye in a patient with cancer of the vulva and a single positive lymph node. Gynecologic Oncology 2004; 92: 981-4. [CrossRef]

26. Radziszewski J, Kowalewska M, Jedrzejczak T, KozlowiczGudzinska I, Nasierowska-Guttmejer A, Bidzinski M, et al. The accuracy of the sentinel lymph node concept in early stage squamous cell vulvar carcinoma. Gynecol Oncol 2010; 116: 473-7. [CrossRef]

27. Oonk MH, van Hemel BM, Hollema H, de Hullu JA, Ansink AC, Vergote I, et al. Size of sentinel-node metastasis and chances of non-sentinel-node involvement and survival in early stage vulvar cancer: results from GROINSS-V, a multicentre observational study. Lancet Oncol 2010; 11: 646-52. [CrossRef]

28. Zambo K, Schmidt E, Hartmann T, Kornya L, Dehghani B, Tinneberg HR, et al. Preliminary experiences with sentinel lymph node detection in cases of vulvar mailgnancy. Eur J Nucl Med Mol Imaging 2002; 29: 1198-2000. [CrossRef]

29. Van der Zee AG, Oonk MH, De Hullu JA, Ansink AC, Vergote I, Verheijen $\mathrm{RH}$, et al. Sentinel node dissection is safe in the treatment of early-stage vulvar cancer. J Clin Oncol 2008; 26: 884-9. [CrossRef] 